\title{
South-South trade and South-North trade: which contributes more to development in Asia and South America? Insights from estimating income elasticities of import demand
}

\author{
Thomas Bernhardt
}

ABSTRACT

The experience of the global economic crisis led developing countries to intensify the diversification of sources of growth, seeking alternative models of economic development. The expansion of South-South trade assumed greater significance in the context of this search. Yet how promising a strategy is this? In attempting to answer this question, this paper documents the evolution of South-South trade and puts forward some theoretical considerations. It then undertakes an econometric analysis to estimate the income elasticities of import demand in bilateral trade relationships among developing Asian and South American countries and two key Northern markets. On applying an ARDL model, the analysis yields mixed results in terms of whether South-South trade presents higher income elasticities than South-North trade. Still, the findings show that South-South trade can be an alternative source of growth, especially if South-North income and import growth differentials persist. 


\section{I}

\section{Introduction}

The dramatic breakdown of world trade in the wake of the recent global financial and economic crisis has called into question the sustainability of the prevailing export-led growth regime pursued by a number of developing and emerging economies (Griffith-Jones and Ocampo, 2009; Ocampo, 2009). Traditionally, and also in the recent past, many developing countries have relied for their exports mainly on primary commodities and resource-based products, which they have generally traded for imports of more technology- and skillintensive manufactures, primarily from rich countries in the global North (UNCTAD, 2005, p. 129). The recent crisis made clear the necessity for export-dependent countries to diversify their sources of growth. One element of this could include the diversification of their export destinations. An increase in South-South trade, i.e., of trade between developing countries, might not only offer one way out of the crisis in the short run but also, from a longer-term perspective, be an element of a more reliable and sustainable development strategy for lower-income countries (Milberg and Winkler, 2010). ${ }^{1}$

Indeed, early developmentalist economists such as Myrdal (1956) and Lewis (1980) were already pointing to the potential of South-South trade as a driver of economic development. They emphasized that SouthSouth integration could help developing countries to reduce their dependence on Northern markets and also overcome bottlenecks related to resource endowments and the size of domestic markets, thereby promoting industrialization. Later on, scholars such as Amsden (1987)

$\square$ The author currently works at the Myanmar Development Resource Institute-Centre for Economic and Social Development (MDRI-CESD), but large parts of this paper were written during his time at the New School for Social Research. The views expressed herein are his own and do not necessarily reflect the views of MDRI-CESD. He gratefully acknowledges valuable comments from Christian Schoder, Matthias Schnetzer, Manuel Albaladejo, Will Milberg, Christian Proaño, Gary Gereffi and an anonymous referee on earlier versions of this paper. All remaining errors are his own.

1 The "South" is defined here as all countries classed as developing economies by UNCTADstat. This includes all countries on the African continent, all Asian countries except Israel, Japan and the countries of the former Soviet Union, the Middle East, and the whole of the Americas excluding Bermuda, Canada, Greenland, Saint Pierre and Miquelon and the United States. See [online] http://unctadstat.unctad.org/EN/ Classifications/DimCountries_DevelopmentStatus_Hierarchy.pdf. and Lall (1987) noted the increasingly industrialized nature of South-South trade, characterized as it was by a higher share of capital- and skill-intensive goods than developing countries' exports to the North, and "saw [South-South] trade in sophisticated manufactures as a potential catalyst for dynamic gains aiding industrialization and technology transfer within the South" (Dahi and Demir, 2008, p. 267). More recently, a number of international development agencies, especially those belonging to the United Nations system, have shown renewed interest in South-South cooperation and trade as a vehicle for addressing various of the world's development challenges, and as an ever more promising avenue towards development (see UNCTAD, 2005, 2010 and 2011; UNIDO, 2006; ADB, 2011; World Bank, 2011; UNDP, 2013, chap. 2).

So how do South-South trade figures react to changes in economic activity and income in the developing countries concerned? How does this compare to the implications of an increase in income in their rich-country trading partners? Can South-South trade be shown, on the basis of econometric estimations of income elasticities, to be a (more) promising source of demand and economic growth overall?

This paper attempts to answer these questions by taking a look at the empirics of certain segments of South-South trade, specifically both interregional and intraregional trade between Asian and South American economies, and comparing this to the trade of these countries with representatives of the rich global North, namely the eurozone and the United States. To this end, the paper tries to find out whether South-South trade is typically characterized by higher income elasticities and is therefore a more promising source of growth than developing countries' exports to rich countries, by focusing on a sample of bilateral Asia-South America trade relationships.

To document changes in international and regional trade patterns, this Introduction is followed in section II by a brief empirical account of the magnitude of SouthSouth trade and its development over the past decades. Next, section III examines how South-South trade could be beneficial for developing countries, while section IV discusses why the income elasticities of import demand can serve as a useful indicator of the potential for South-South 
trade to become a driver of economic development in Asia and South America. Section V outlines the econometric model and the empirical approach, section VI sets out the focus of the analysis and presents the regression results and section VII compares the potential of South-South trade and South-North trade to drive income growth in Asia and South America; lastly, section VIII refers to policy consequences and offers some final reflections.

\section{II}

\section{An empirical account of South-South trade: magnitude, developments and patterns}

The purpose of this section is to give a brief empirical account of the magnitude of South-South trade and its development over the past decades. In doing so, it seeks to examine the driving forces of South-South trade. What do South-South trade flows look like, and what is the geographical composition and structure of such flows?

The general export performance of developing countries is the starting point for this analysis. Figure 1 plots the long-run trend of exports from the South since the Second World War. It reveals three distinct phases. First, in the two and a half decades that followed the conflict, the world trade share of exports from the South declined from over $30 \%$ to less than $20 \%$. The second phase, dominated by high commodity prices from the mid-1970s on, saw a dramatic increase in the South's share of world exports, which shot up to almost $30 \%$ and remained at over $25 \%$ until the mid-1980s, before a decrease in oil and commodity prices brought it back down to $21 \%$ by 1987 . Since then, the South's export share has experienced a continuous upward trend, reaching a record level of $44 \%$ in 2012 (representing an export value of US\$ 6.14 trillion). ${ }^{2}$ As figure 1 reveals, this upward trend has been driven above all by the economies of developing Asia. Importantly, the growth of exports from developing countries in this current phase since the mid-1980s has involved a rise not only in trade values but also in volumes. Shirotori and Molina (2009, p. 2) reported that the volume of exports from the South to the world had quintupled since the 1980s, while world exports had increased only threefold. On average, exports from the South grew by $7 \%$ a year from 1980, exceeding the average annual rate of growth in world exports overall (6\%).

\footnotetext{
2 Average annual growth rates during these three phases were $6 \%$, $14 \%$ and $11 \%$, respectively.
}

FIGURE 1

Exports from the South as a share of total world exports, 1948-2012 (Percentages)

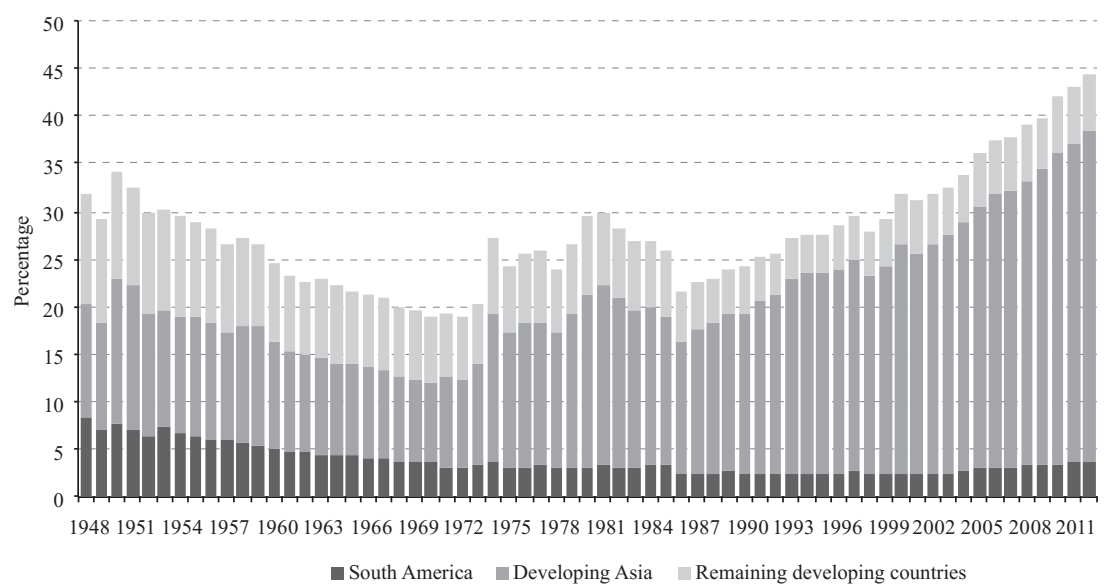

Source: Prepared by the author, on the basis of data from the UnCTADstat database. 
The greater part of the growth in exports from the South can be explained by the expansion of South-South trade (see Hanson, 2012). This is particularly true for the past decade. In 2011, total South-South exports amounted to US\$ 4.3 trillion, accounting for $55 \%$ of total exports from the South. The significant growth of South-South exports becomes evident when they are compared to exports from the South to the rest of the world. Figure 2 shows that, between 1995 and 2011, the average annual growth of South-South exports was a remarkable 13\%, far exceeding the annual growth of exports to the rest of the world, put at $9.5 \%$. Comparing these figures with older data reported by Shirotori and Molina (2009, p. 3) reveals that the growth gap has actually widened over the past few years: in the 10 years from 1995 to 2005, developing countries' exports to other developing countries rose by an annual average of $11.5 \%$, while their exports to the rest of the world grew by an annual $9.3 \%$, yielding an annual growth differential of 2.2 percentage points that pales beside the 3.5 percentage point export growth gap for the period from 2005 to $2011 .^{3}$ As can be seen in figure 2 , this surge in exports to Southern markets has been a shared feature across continents, with developing Asia recording the highest annual growth rates (averaging 13.1\% between 1995 and 2011) and developing Africa and the developing countries of the Americas being more or less in lockstep (about $12.6 \%$ annually in both cases).

3 All data reported in this section were drawn from the UNCTADstat database [online] http://unctadstat.unctad.org.
However, there are certain regional differences as regards the weight of the South as an export market. In 2011, developing Asia shipped considerably more than half of its total exports (59\%) to other countries in the global South. In other regions, the share was lower. In Africa, exports to the South accounted for $43 \%$ of the total. The overall figure for the Americas was 39\%, although for the South America subregion the figure was much higher, at $54 \%$.

Two further aspects are worth noting. First, SouthSouth trade is clearly dominated by Asia, which has acted as a "locomotive of South-South trade" (UNCTAD, 2008, p. 3). Indeed, Asia is both the largest exporter and the largest importer in South-South trade, with its exports (including intraregional exports) accounting for $84 \%$ of total South-South trade in 2012. This predominance can be explained by Asia's sheer economic size, but also by its function as the world's most important hub for international trade and by the fact that it has a greater share of this trade than the other two developing regions, Africa and the Americas (Shirotori and Molina, 2009). ${ }^{4}$ Second, interregional trade is currently only a rather minor component of South-South trade, which mostly takes place between countries belonging to the same region. Asia once again plays the leading role, with its high degree of regional integration, often in the form of regional supply chains, being a major reason.

\footnotetext{
4 Many export-oriented production networks are concentrated in Asia, with China, Japan and the Republic of Korea at their centre. This phenomenon is known as "Factory Asia."
}

FIGURE 2

Average annual export growth rates, 1995-2011 (Percentages)

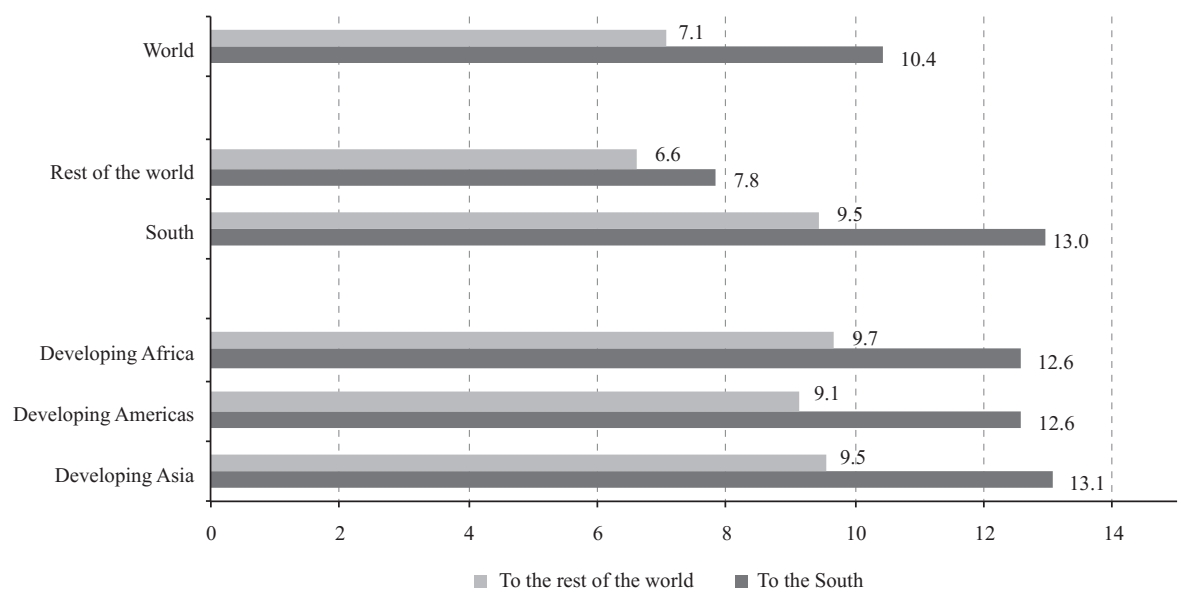

Source: Prepared by the author, on the basis of information from the UNCTADstat database. 
The rapid expansion of South-South trade cannot be understood without proper recognition of the increasingly important role of global and also regional production networks, something that, in turn, also goes a long way towards explaining the predominance of Asia in SouthSouth trade (and indeed in global trade). For Shaffaeddin (2008), the rapid growth of trade between Asian countries has, above all, been the result of industrialization and industrial collaboration in the region in the form of production-sharing. Athukorala (2011, p. 12) points out that, in Asia, the elaborate "intercountry division of labor within production networks has contributed significantly to strengthening trade complementarity among countries in the region," thereby further accelerating intraregional trade. The analysis that follows will seek to acknowledge these different aspects of South-South trade by looking at both interregional trade between and intraregional trade flows within Asia and South America.

\section{III}

\section{Why should South-South trade be beneficial for developing countries?}

Is South-South trade more advantageous than SouthNorth trade for developing countries? And why should a shift from the traditional South-North trade scheme to more South-South trade bring benefits for lowerincome countries? Theoretically, at least three reasons can be found.

Firstly, South-South trade can potentially imply an increase in export volume growth. Indeed, for much of the past 30 years (and particularly the past decade), economic growth has been far more dynamic in the poorer countries of the global South - particularly the large "Asian driver economies" (Kaplinsky and Farooki, 2010, p. 11) of China and India — than in the rich countries of the North. The sheer growth performance of developing economies and the growth gap between them and the advanced economies make the former promising and appealing export markets, not least for outward-oriented developing countries. Accordingly, Fugazza and Vanzetti (2008) find that the potential gains from removing SouthSouth trade barriers would be considerably higher than those from opening up Northern markets (see also ADB, 2011; IMF, 2011, and Wignaraja, Ramizo and Burmeister, 2012). Indeed, there has already been an impressive expansion of South-South trade, especially during the last two decades, with a higher rate of growth than world trade (Shirotori and Molina, 2009). Such larger export volumes are potentially income-generating. However, a certain portion of this South-South trade has happened only on paper. The increasing integration of Southern producers into international production networks (often called global value chains) has led to a fragmentation of production processes and a new pattern of trade, in which goods travel between various locations before reaching the final consumer. Therefore, South-South trade statistics include a certain degree of doublecounting and thus have to be interpreted with caution (ADB, 2011, p. 50).

A second way in which South-South trade can potentially be advantageous for participating countries is via an increase in the technological content of the typical goods in their export baskets. In other words, South-South trade can potentially benefit developing countries if it allows or even promotes industrial upgrading in their production structures. In particular, this could involve a shift from exporting goods with low skill intensity and low value added to goods with high(er) knowledge intensity and high(er) value added. Yet the evidence for this hypothesis is mixed. Shirotori and Molina (2009), for example, point out that the dominant sector in SouthSouth trade is manufacturing, and Dahi and Demir (2008) that the share of manufacturing exports in total South-South exports has more than doubled in the last 30 years. Klinger (2009) finds that for some developing countries, particularly in Africa, Latin America and Central Asia, exports to the South are more sophisticated and provide more learning effects than exports to the North. This supports Dahi and Demir's (2008) observation that Southern exports of technology- and skill-intensive manufactures destined for Southern markets have grown faster than exports to Northern markets, so that SouthSouth trade in manufactures is now characterized by higher capital, technology and skill intensity than SouthNorth trade. On the other hand, UNCTAD (2005) revealed that the most dynamic sector in terms of export value in 
South-North trade over the previous three decades had been medium-skill-intensive manufacturing, whereas in South-South trade it was labour- and resource-intensive manufactures that registered the most dynamic growth. Moreover, Kaplinsky, Terheggen and Tijaja (2010), and Kaplinsky and Farooki (2010) predict that the shift from Northern to Southern final demand sources (expected as a consequence of recent global economic dynamics and particularly the recent crisis) will entail a change in the structure and nature of import demand, with product and production standards losing importance in global value chains and with suppliers in developing countries being forced to focus more on unprocessed products (with less value added and less potential for learning and upgrading).
Thirdly, South-South trade could potentially benefit developing countries by enhancing the reliability of the demand for their exports, which would be of great help in their struggle for macroeconomic stability. One underlying reason for this could be export diversification. It is a widespread phenomenon among developing countries that their basket of export goods and their export markets are highly concentrated. Export diversification would reduce this concentration and thereby make developing countries less dependent on one or a few export goods, destinations or both. Another explanation could be that South-South trade flows are characterized by a higher income elasticity of import demand than South-North trade flows. That is what the remainder of this paper will focus on.

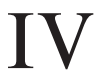

\section{The income elasticity of import demand: does South-South trade benefit development} in Asia and South America?

Basically, the income elasticity of demand measures the responsiveness of the quantity demanded of a good to changes in the income of the economic agents who consume it. In the context of international trade, the income elasticity of import demand thus indicates the responsiveness of import flows to changes in the income of the importing country. The higher the elasticity, the more responsive the demand for imports will be when the importing country's income rises.

The main purpose of this paper is to arrive at some basic estimates for the income elasticities of import demand in South-South trade by comparison with South-North trade. The key question is: which of these elasticities is greater?

The hypothesis that income elasticities of import demand are higher in South-South trade can be based on both supply-side and demand-side arguments. The supply-side dimension relates to the second factor noted in section III, namely the composition of developing countries' export baskets. As discussed above, there are indications that South-South trade flows include a higher share of goods that are usually expected to be characterized by a higher income elasticity of demand. For example, agricultural or food products are usually said to have a low (or even negative) income elasticity of demand; additional income, especially at higher levels, is expected to be decreasingly spent on food. On the other hand, most manufactures are generally expected to have a high income elasticity of demand. If the typical basket of goods that a developing country imports from another developing country contains more manufactures relative to primary commodities (or more high-skill-intensive goods relative to low-skill-intensive goods) than the typical basket of goods that an advanced economy imports from that developing country, then South-South trade can be expected to be characterized by a higher income elasticity of import demand than South-North trade. As mentioned above, the most traded sector in overall South-South trade is manufacturing, although this does not necessarily hold true for each and every country involved. There is, in fact, quite a degree of variation across regions, and while it is true that manufacturing is 
the most traded sector in total South-South trade, with a share of $58 \%$, this result is driven by the dominance of Asia, where manufacturing accounts for $64 \%$ of all South-South exports. The share in the other regions is much lower (developing countries of the Americas 35\%, South America 28\%, Africa 16\%). ${ }^{5}$

The demand-side dimension, on the other hand, refers to the complementarity of production structures and trade. Due to differences in their stage of development in general and industrialization in particular, developing countries typically differ from advanced economies in the structure and nature of demand (Kaplinsky and Farooki, 2010). Specifically, the ongoing rapid industrialization of the dynamic Asian economies in particular entails growing demand for raw materials, metals and energy. Moreover, urbanization and changing lifestyle and preference patterns also mean an increasing demand for imported food and agricultural goods, which can be quite sizeable given the huge size of the Chinese and Indian populations (UNCTAD, 2005, chap. 2). All this suggests that these industrializing Southern countries offer promising export markets to other developing countries that specialize in the export of commodities, at a time when production structures in industrial countries of the North are increasingly shifting from industry to services, implying reduced demand for raw materials and industrial inputs there. At the same time, the growing integration of developing countries into regional and global production networks means that their demand for intermediate and manufactured goods is also rising. Athukorala (2011) argues that the increasing integration of the South into regional and global value chains has contributed not only to the diversification of production structures there but also to growing trade complementarity among Southern economies. Hitherto, however, the demand for the final goods produced in such global value chains has been chiefly from Northern countries. This might change now as a result of the far-reaching repercussions of the recent global economic crisis.

Yet a shift of export markets from the North to the South will have significant implications for the structure and nature of demand. While consumers' preferences

\footnotetext{
${ }^{5}$ It is also interesting that this share has gone down in all regions since the year 2000 (when it stood at $42 \%$ in South America, for example), most probably reflecting the commodity price boom.
}

in the North are increasingly based on product quality, innovation and differentiation, in developing countries the most important determinant of demand is very often simply the price of a good (Kaplinsky and Farooki, 2010). Moreover, the structure of demand is different not only for consumer goods but also for capital goods. In fact, "South-South trade offers developing countries access to affordable capital goods that are often more appropriate to their needs than are capital goods from richer countries and that are therefore more likely to be acquired, adopted and imitated" (UNDP, 2013, p. 46). The widespread expectation that economic growth will be much more dynamic in the South than in the North, at least in the short to medium run, implies that there will be rising demand for this type of goods. Since such goods are predominantly produced in developing countries, import demand from the South complements export supply from the South, thus lending further momentum to South-South trade. This is confirmed by Shirotori and Molina (2009), who find that sectoral specialization in South-South trade and thus trade complementarity are indeed increasing. In a similar vein, while focusing more narrowly on trade between low-income countries (LICS) and the BRICs (Brazil, Russian Federation, India and China), an International Monetary Fund (IMF) paper finds strong economic complementarities between these two groups of countries based on complementarities in resource endowments and production structures. Indeed, using a trade complementarity index, the paper shows that "export complementarity is generally higher between LICs and China or India than between LICs and the United States or the EU" (IMF, 2011, p. 14).

To sum up, the hypothesis that South-South trade is characterized by higher income elasticities of import demand than South-North trade may derive from the assumption that the former is based on different export portfolios (with a higher share for manufacturing and more sophisticated goods) and that it features higher trade complementarity (import demand meets export supply). Of course, a higher income elasticity of Southern import demand will make the expansion of South-South trade particularly beneficial to developing countries if the first condition mentioned above, namely the existence of a growth gap between the South and the North, remains true. 


\section{V}

\section{Empirical approach and model}

With regard to the econometric model to be estimated, this study employs a standard import demand function based on the imperfect substitution model as outlined by Goldstein and Khan (1985), where foreign and domestic products are assumed to be imperfect substitutes. This can be written as follows:

$$
\ln M_{t}^{j}=\alpha+\beta \ln Y_{t}+\gamma \ln E_{t}^{j}+\varepsilon_{t}
$$

where $\ln$ represents the natural logarithm function, $M$ is the demand for imports from country $j, Y$ is real domestic income, $E$ is the real bilateral exchange rate between the home country and country $j$ at time $t$ (defined as the number of units of domestic currency per unit of foreign currency adjusted for domestic and foreign price levels) and $\varepsilon_{t}$ is the random error term. ${ }^{6}$ The hypothesis is that higher income is related to higher import demand, i.e., that parameter $\beta$ is positive. Parameter $\gamma$ is expected to be negative, implying that a real appreciation of the domestic currency is associated with higher import demand.

The analysis then follows the approach pursued by Milberg and Winkler (2010), Bahmani-Oskooee and Kara (2005) and Bahmani-Oskooee, Goswamil and Talukdar (2005). These authors estimate long-run income elasticities of import demand for the United States, Canada and a number of different countries, respectively, employing an autoregressive distributed lag (ARDL) approach to cointegration which, according to Pesaran, Shin and Smith (2001), yields consistent estimates of the longrun coefficients irrespective of whether the regressors are stationary or not (i.e. whether they are integrated of order 0 or 1 , or higher: $\mathrm{I}(0)$ or $\mathrm{I}(1))^{7}$ This approach

\footnotetext{
6 Two caveats have to be mentioned here. First, this model mixes data in volumes (gross domestic product) with data in values (imports). This may somewhat bias the estimates of income elasticities. Second, as imports are measured in value terms, increases may be driven by rises in goods prices. This is of particular importance for South American exports, whose growth between 2004 and 2011 was propelled to a significant extent by rising commodity prices. Future econometric estimations should thus seek to capture such price fluctuations too.

7 The underlying issue is that most of the variables included in the import demand function can be expected to have non-stationary time series (i.e., be integrated of order 1 or higher), which, when used in a standard ordinary least squares (oLs) regression, can lead to misleading results and fallacious inferences in what is known as the "spurious
}

is thus convenient as it does not require pre-testing for unit roots and as it also possesses desirable small sample properties (see Pesaran and Shin, 1999, or Panopoulou and Pittis, 2004, for example), which is of relevance for the undertaking here. ${ }^{8}$ The ARDL approach includes lagged level variables and adds short-run dynamics (by including contemporaneous and lagged differenced variables) to a long-run estimation equation like the one given above, yielding:

$$
\begin{gathered}
\Delta M_{t}^{j}=\alpha+\sum_{i=1}^{n} \beta_{i} \Delta \ln Y_{t-i}+\sum_{i=1}^{n} \gamma_{i} \Delta \ln E_{t-i}^{j} \\
+\sum_{i=1}^{n} \delta_{i} \Delta \ln E_{t-i}^{j}+v_{1} \ln Y_{t-1}+v_{2} \ln E_{t-1}^{j} \\
+v_{3} \ln M_{t-1}^{j}+\epsilon_{t}
\end{gathered}
$$

In equation (2), the lagged level variables for $Y$, $E$ and $M$ constitute the (lagged) error correction term.

regression" problem. To avoid this problem, several cointegration estimation techniques have been developed in the econometric literature, one of which, the ARDL framework, is applied here.

8 Because of its desirable properties as outlined above, the ARDL framework has been employed in a number of recent papers that investigate and estimate trade elasticities, including Bahmani-Oskooee and Kara (2005), Bahmani-Oskooee, Goswamil and Talukdar (2005), and Milberg and Winkler (2010), as well as Chang, Ho and Huang (2005) for the Republic of Korea, Uz (2010) for Turkey, Yin and Hamori (2011) for China, and Grullón (2012) for the Dominican Republic. Earlier empirical literature estimating income elasticities of import demand also applied other econometric methods, though not all made use of cointegration techniques. Kwack and others (2005), for example, conduct a simple oLs panel estimation for a number of countries. Thorbecke and Komoto (2010) present estimates of aggregate trade elasticities for the United States and a number of Asian countries, using the dynamic ordinary least squares (DOLS) estimator developed by Stock and Watson (1993), which adds lags and leads of the regressors. Uz (2010) actually draws on five different methods to estimate long-run (cointegrating) trade relationships for Turkey, including DOLS and ARDL. Yin and Hamori (2011) estimate long-run income elasticities for China using not only the ARDL framework but also the DoLs technique. The present study, however, refrains from using the DOLS approach, since adding lags and leads for the explanatory variables requires the availability of long time series for the variables in the model, a condition not easily met for developing countries, including those that will be the focus of analysis in this paper. 
Depending on the F-statistic, this lagged error correction term should be retained or excluded from the equation, with Pesaran, Shin and Smith (2001) providing critical value bounds. If the F-statistic is greater than the upper critical value bound reported by these authors, the null hypothesis of $v_{1}=v_{2}=v_{3}=0$ is rejected, i.e., the lagged level variables are cointegrated and kept in equation (2). ${ }^{9}$

${ }^{9}$ See annex 1 for information on data sources and annex 2 for further details on the estimation procedure.

\section{VI}

\section{Focus of the analysis and regression results}

The central analysis of this paper will focus on one particular intercontinental (or interregional) segment of South-South trade, namely the trade between Asian and South American countries, as well as on intracontinental trade within these two regions. The reason for this choice is that it promises to be a particularly interesting example given that the "scope for exploiting interregional trade (...) is particularly evident between Asia and the Americas" (Shirotori and Molina, 2009, p. 11). Indeed, trade complementarity between Asia, Central America and South America seems to be particularly pronounced (UNCTAD, 2008, p. 14). Taking a look at the list of the sectors that are most traded between the two regions provides some support for this notion. While Asia's exports to the Americas largely consist of products from the manufacturing sector, South America's exports to Asia are dominated by natural resource-based and agricultural products. In addition to analysing interregional trade between Asia and South America, it is also interesting to compare the income elasticities of import demand in interregional and intraregional trade. In line with the gravity model literature, which emphasizes the importance of factors such as geographical proximity, shared borders, a common language, cultural familiarity, etc., as drivers for trade (see Kwack and others, 2005, for example), it can be hypothesized that elasticities are higher in intraregional trade than in interregional trade. This is checked here by analysing elasticities in trade within Asia and within South America.

As stated above, intraregional trade is very important for developing Asia. In fact, 51.8\% of all developing Asian exports go to fellow Asian countries within the region (up from $42.2 \%$ in 1995). In South America, on the other hand, intraregional trade is not as significant. While intraregional exports have grown fast, and indeed quadrupled during the last 15 years, they have not kept pace with South America's overall exports to the world (which quintupled in the same period), so that the share of intraregional exports in total exports dropped from $24.7 \%$ in 1995 to $19.3 \%$ in 2011.

The analysis here will concentrate on key players in the two regions, namely China, India, Indonesia and the Republic of Korea as representatives of developing Asia, and Argentina, Brazil, Chile and Peru as representatives of South America. In the final step, it will examine how income elasticities in South-South trade compare with those in South-North trade, as proxied by these countries' trade with the United States and the eurozone (those countries within the European Union (EU) that have adopted the euro as their common currency).

\section{South-South trade}

The objective of the first set of regressions is to estimate the income elasticities that characterize the different bilateral trade relations in both interregional South-South trade (i.e., between South American countries on the one hand and Asian countries on the other) and intraregional South-South trade (i.e., within South America and Asia, respectively). The coefficients estimated for the income elasticities of import demand for all bilateral trade relations can be found in table 1 .

\section{(a) Income elasticities of South American import demand} This study will initially look at bilateral trade flows into South American countries, be they from Asia or from fellow South American countries. As stated above, the income elasticities of South American import demand for goods from Asian or South American trading partners are of particular interest. The estimation results for the corresponding coefficients delivered by the final regression models are shown in rows 1 to 4 of table $1 .{ }^{10}$

\footnotetext{
${ }^{10}$ More detailed estimation results, not included in this paper owing to space constraints, are provided in a supplementary annex (annex C). This information is available from the author upon request.
} 
TABLE 1

Estimated coefficients for the income elasticities of bilateral import demand

\begin{tabular}{|c|c|c|c|c|c|c|c|c|}
\hline \multirow{2}{*}{ Importer } & \multicolumn{8}{|c|}{ Trade partner } \\
\hline & Argentina & Brazil & Chile & Peru & China & India & Indonesia & Republic of Korea \\
\hline Argentina & $\ldots$ & $0.173 * * *$ & $0.470 * * *$ & $0.394 * *$ & $0.222 * *$ & $0.185^{* * *}$ & $0.255^{* * *} *$ & $0.549 * * *$ \\
\hline Brazil & $0.629 * * *$ & $\ldots$ & $0.424 * * *$ & $0.407 * * *$ & $0.560 * * *$ & $0.890 * * *$ & $0.599 * * *$ & $0.427 * * *$ \\
\hline Chile & 0.490 & $0.715 * * *$ & $\ldots$ & $0.247 * *$ & $1.543 * * *$ & $0.811^{* * *}$ & $0.591 * * *$ & $0.628 * * *$ \\
\hline Peru & $0.517 * * *$ & $0.386 * * *$ & $0.528 * * *$ & $\cdots$ & $0.526 * * *$ & $1.502 * * *$ & $0.494 * * *$ & $0.529 * * *$ \\
\hline China & $0.375 * *$ & $0.899 * * *$ & $0.613^{* * * *}$ & $0.465 * * *$ & $\cdots$ & $\begin{array}{l}1.577 \mathrm{a} \\
\left(0.705^{* * *}\right)\end{array}$ & $0.936 * * *$ & $\begin{array}{l}0.500 \mathrm{a} \\
(0.239 * * *)\end{array}$ \\
\hline India & $0.254 * * *$ & $1.564 * * *$ & $1.316^{* * * *}$ & $1.797 * * *$ & $\begin{array}{c}0.676 a \\
(0.232)\end{array}$ & $\cdots$ & $0.402 * * *$ & $\begin{array}{c}1.549 \mathrm{a} \\
\left(0.737^{* *}\right)\end{array}$ \\
\hline Indonesia & $0.761 * * *$ & $0.999 * * *$ & $1.165^{* *}$ & $0.285^{* * *} *$ & $0.841^{* * *}$ & $2.020 * * *$ & $\cdots$ & $0.344 * * *$ \\
\hline Republic of Korea & $0.751 * * *$ & $0.649 * * *$ & $0.656^{* * * *}$ & $1.118 * * *$ & $0.674 * * *$ & $1.214 * * *$ & $0.500 * * *$ & $\ldots$ \\
\hline Eurozone & $0.261 * *$ & $1.126 * * *$ & 0.124 & $0.532 *$ & $0.685 * * *$ & $0.295 * * *$ & $0.462 * * *$ & $1.192 * * *$ \\
\hline United States & $1.128 * * *$ & $0.913 * * *$ & $1.740 * * *$ & $1.609 * * *$ & $2.606 * * *$ & 0.244 & $0.288 * *$ & 0.0218 \\
\hline
\end{tabular}

Source: Prepared by the author.

${ }^{\text {a }}$ The short-run income elasticity of import demand, calculated as the sum of all statistically significant short-run coefficients, i.e. $\sum_{i=1}^{n} \beta_{i}$ (see Debelle and Vickery (1998) or Chatelain and Tiomo (2001)). In accordance with Milberg and Winkler (2010, p. 66), the coefficient estimated for the first differenced income variable is also reported (in brackets).

* Significant at $10 \%$; ** significant at $5 \%$; *** significant at $1 \%$.

Table 1 shows that the income elasticities of import demand in interregional trade flows from Asia to South America range from a minimum of 0.19 (in the case of Argentine imports of Indian merchandise) to a maximum of 1.54 (for Chilean imports from China). More precisely, the income elasticities of Argentine imports from China, India, Indonesia and the Republic of Korea are 0.22, $0.19,0.26$ and 0.55 , respectively, indicating that a $1 \%$ increase in Argentine income will increase imports from China by $0.22 \%$, from India by $0.19 \%$, from Indonesia by $0.26 \%$ and from the Republic of Korea by $0.55 \%$. Meanwhile, a $1 \%$ increase in Brazilian income will boost Brazil's imports from China by $0.56 \%$, from India by $0.89 \%$, from Indonesia by $0.60 \%$ and from the Republic of Korea by $0.43 \%$. Income elasticities for Chile are quite high at 1.54, 0.81, 0.59 and 0.63 for its imports from China, India, Indonesia and the Republic of Korea, respectively. Finally, if Peruvian gross domestic product (GDP) grows by $1 \%$, the largest impact will be on Peru's imports from India (1.50\%) and the smallest on its imports from Indonesia $(0.49 \%)$. On average, a $1 \%$ increase in the income of the four
South American countries leads to a $0.644 \%$ increase in bilateral imports from the four Asian economies. In other words, bilateral trade flows from Asia to South America are characterized by a simple (unweighted) average income elasticity of import demand of circa 0.6.

Looking now at intraregional trade, table 1 shows that the income elasticities of import demand in trade flows within South America vary from a minimum of 0.17 (in the case of Argentine imports from Brazil) to a maximum of 0.72 (for Chilean imports from Brazil). Trade elasticities are particularly low in the case of Argentina's imports from its fellow South American partners, and only slightly higher for imports by Brazil, Chile and Peru. The simple, unweighted average of income elasticities of import demand in intraregional South-South trade between South American countries is a mere 0.555 (see table 2). Consequently, intraregional trade in South America is generally characterized by lower income elasticities than the subregion's extraregional imports from Asia (which average 0.644), contradicting the hypothesis of this study. 
TABLE 2

Simple average of the income elasticities of import demand in South-South and South-North trade

\begin{tabular}{|c|c|c|}
\hline \multirow{3}{*}{ Importer } & \multicolumn{2}{|c|}{ South-South trade } \\
\hline & \multicolumn{2}{|c|}{ Trade partner } \\
\hline & Asia & South America \\
\hline Asia & 0.940 & 0.854 \\
\hline South America & 0.644 & 0.555 \\
\hline \multirow{3}{*}{ Importer } & \multicolumn{2}{|c|}{ South-North trade } \\
\hline & \multicolumn{2}{|c|}{ Trade partner } \\
\hline & Asia & South America \\
\hline Eurozone & 0.658 & 0.511 \\
\hline United States & 0.790 & 1.347 \\
\hline
\end{tabular}

Source: Prepared by the author.

(b) Income elasticities of Asian import demand The second part of this study of South-South trade consists in looking at bilateral trade flows into Asia. Rows 5 to 8 of table 1 report the estimated coefficients representing the income elasticities of Asian import demand for goods from both South American and fellow Asian trading partners.

As table 1 shows, the income elasticities of import demand in interregional trade flows from South America to Asia range from a minimum of 0.25 (for India's imports of Argentine merchandise) to a maximum of 1.80 (for Indian imports from Peru). In general, the income elasticities of the demand for imports from South America seem to be highest on average in India among the Asian countries in the sample. More precisely, the estimated income elasticities of Indian imports from Argentina, Brazil, Chile and Peru are $0.25,1.56,1.32$ and 1.80, respectively. Meanwhile, a $1 \%$ increase in Chinese income is estimated to trigger increases of $0.38 \%, 0.90 \%, 0.61 \%$ and $0.47 \%$ in the country's imports from Argentina, Brazil, Chile and Peru, respectively. In the case of Indonesia, a 1\% increase in GDP will raise its imports from Chile the most $(1.17 \%)$ and those from Peru the least $(0.29 \%)$. Finally, if income in the Republic of Korea grows by $1 \%$, its imports from Peru will increase by $1.12 \%$ but those from Brazil only by $0.65 \%$. On average, a $1 \%$ rise in the income of the four Asian countries included in the sample generates a $0.854 \%$ increase in their bilateral imports from the four South American economies, i.e., interregional trade flows from South America to Asia are characterized by an average income elasticity of bilateral import demand of circa 0.9 .
Before turning to intraregional trade within Asia, a note of caution is warranted in that, in fact, not all the values in table 1 are strictly comparable. In four cases (China's imports from India and the Republic of Korea and India's imports from China and the Republic of Korea), econometric exercises indicated specification problems which led to the abandonment of the error correction term included in the original model. ${ }^{11}$ For these four cases, table 1 gives only the short-run effects of income changes on import demand (i.e., the effects of $\Delta \ln Y_{t-\mathrm{i}}$ ), while all other entries in table 1 represent long-run income elasticities of import demand. In fact, table 1 reports two figures for these four cases. First, it indicates the sum of all statistically significant short-run coefficients, i.e., $\sum_{i=1}^{n} \beta_{i}$, as an approximation to the long-run income effects (which is in line with Debelle and Vickery (1998), and Chatelain and Tiomo (2001), for example). Additionally, it reports (in brackets) the coefficient estimated for the first differenced income variables $\left(\beta_{l}\right)$, following the approach taken by Milberg and Winkler (2010, p. 66).

\footnotetext{
11 In all four cases, as reported in tables C.5 and C.6 of annex C, the F-statistics exceed the upper critical value bound at the $10 \%$ significance level as specified by Pesaran, Shin and Smith (2001), indicating that the lagged error correction term should be excluded from the equation. However, since it is the coefficient for the lagged level variable for $\mathrm{Y}$ (which is part of the error correction term) that gives us the long-run "equilibrium" income elasticity of import demand, it is only possible to report the short-run income elasticities for these four bilateral trade relationships. For further details, see the explanations provided in annex $\mathrm{C}$.
} 
As can be seen in table 1, income elasticities of import demand in intraregional trade flows within Asia range from a minimum of 0.34 (in the case of Indonesian imports from the Republic of Korea) to a maximum of 2.02 (for Indonesian imports from India). In general, Indonesia reports the highest trade elasticities for its intraregional imports, followed by China, with a $1 \%$ increase in Chinese income leading to an estimated $1.58 \%$ increase in its imports from India, a $0.94 \%$ rise in imports from Indonesia and a $0.50 \%$ rise in imports from the Republic of Korea. Meanwhile, income elasticities are also comparatively high in trade between India and the Republic of Korea: a 1\% rise in India's income is estimated to expand its imports from the Republic of Korea by $1.55 \%$, while if the Republic of Korea's real GDP grows by $1 \%$, its imports from India will increase by $1.21 \%$. Broadly speaking, intraregional trade between Asian economies is therefore fairly income-elastic. The simple average of the income elasticities of import demand in intraregional South-South trade within Asia is calculated to be 0.94 . This value not only exceeds the average elasticities for Asia's extraregional imports from South America (at 0.85), as expected, but is also higher than average income elasticities in intraregional trade within South America (at 0.64) (see table 2), with the latter fact arguably reflecting the more advanced economic integration and more refined production-sharing among Asian countries.

\section{South-North trade}

Since this paper is ultimately interested in comparing the promise held out by South-South trade relative to South-North trade, some idea of the income elasticities of import demand in South-North trade is required. As such, the second set of regressions will seek to estimate the income elasticities that characterize the various bilateral trade relations between the eurozone and the United States on the one hand, and Asian and South American countries on the other.

\section{(a) Eurozone imports from Asia and South America}

The first step in the analysis of South-North trade looks at trade flows from Asia and South America to the eurozone. The estimation results for the income elasticities of eurozone import demand for Asian and South American goods are reported in row 9 of table 1. There it can be seen that income elasticities are highest for the eurozone's demand for imports from the Republic of Korea (at 1.19) and Brazil (at 1.13), and lowest for imports from Chile (at 0.12) and Argentina (at 0.26), while also being fairly low for imports from Peru (at 0.53 ), the fourth South American country included in the sample. Meanwhile, as table 1 reveals, a $1 \%$ increase in eurozone income will generate a $0.69 \%$ rise in eurozone imports from China, a $0.30 \%$ expansion in imports from India, and a $0.46 \%$ increase in imports from Indonesia. Overall, income elasticities are thus higher for the eurozone's demand for imports from Asia (averaging 0.66) than from South America (averaging 0.51) (see table 2).

(b) United States imports from Asia and South America In order to get a more complete picture of South-North trade, the final step of the present analysis consists in estimating the income elasticities of United States import demand for Asian and South American merchandise. The results of the corresponding regressions are exhibited in row 10 of table 1 , which shows that the income elasticities of import demand in trade flows from the South to the United States are highest for China (at 2.61) and rather low for the other Asian countries considered here: 0.29 for Indonesia, 0.24 for India and a mere 0.02 for the Republic of Korea. Meanwhile, United States imports from the sample of South American countries are characterized by quite high income elasticities. More precisely, the income elasticities for United States imports from Argentina, Brazil, Chile and Peru are $1.13,0.91,1.74$ and 1.61 , respectively. On average, a $1 \%$ expansion in United States income will increase United States imports from the four South American economies by $1.35 \%$ but imports from the four Asian countries by just $0.79 \%$. In other words, and contrary to the findings obtained for eurozone imports, average income elasticities are higher for United States demand for imports from South America than for imports from Asia (see table 2).

Comparing the two Northern markets analysed here, it can be observed that, overall, United States import demand is characterized by higher income elasticities than eurozone import demand. While this does not hold true for every single bilateral trade relationship, the simple, unweighted averages reported in the lower panel of table 2 show that average United States income elasticities exceed those of the eurozone for import demand from both Asia (0.79 versus 0.66 ) and South America (1.35 versus 0.51). Comparing South-North trade flows across regions of origin, one finds that, strikingly, the average income elasticities of Northern demand for imports from South America exceed elasticities in trade flows to the global North originating from developing Asian countries ( 0.93 versus 0.72$)$. 
Before undertaking a comparison and discussion of income elasticities in South-South versus South-North trade in section VII below, it is worth briefly crosschecking the above results with those of other empirical studies. However, in making such comparisons across studies, it is important to keep in mind that there are certain differences in the approaches, methodologies and data used which can explain many of the disparities in their findings. Overall, however, the income elasticities of import demand estimated in this study are similar in magnitude to the results obtained by Bahmani-Oskooee and Kara (2005), who report long-run income elasticity estimates ranging from 0.14 for Japan to 2.10 for the United States. The estimates given herein are also consistent with those of Milberg and Winkler (2010), who find (statistically significant) long-run income elasticities of import demand of 0.77 for Taiwan Province of China, 1.24 for Brazil and 1.86 for Germany, while their estimates for China and India comfortably exceed those reported in this paper.

Meanwhile, Grullón (2012), Yin and Hamori (2011) and Chang, Ho and Huang (2005) report estimates of long-run import elasticities that, on average, are slightly higher than those found here, ranging from 1.37 for the Dominican Republic to 1.86 for the Republic of Korea and 2.66 for China. The same goes for Thorbecke and Komoto (2010), who estimate the long-run income elasticities of different countries' import demand in a range from 1.32 for the Republic of Korea and 1.45 for Taiwan to 2.14 for the United States. Similarly, the regressions undertaken by Kwack and others (2005) yield coefficients that are somewhat higher than those reported above, ranging from a minimum of 1.05 for Singapore to a maximum of 3.28 for the Philippines. Yet it is important to emphasize that the findings from all these studies are not entirely comparable with those of the present research, since for each country in their sample they estimate "global" income elasticities of demand for imports from all trading partners of the country in question, whereas the income elasticities estimated in this paper are bilateral. Moreover, the latter two of the above-mentioned studies use annual data (in contrast to the quarterly data employed herein), and their dependent variable is real imports in levels, not in first differences as in the present case.

The studies by Bahmani-Oskooee, Goswamil and Talukdar (2005) and Uz (2010) each investigate income elasticities in bilateral trade relations, using quarterly data and the ARDL approach. Both yield estimates that, in general, are higher than those reported in this study. However, these analyses refer to countries that are not included in the present sample, namely Canada and Turkey. While it is difficult to uncover what explains the differences between the findings of these studies and those set out in this paper, it has to be pointed out that Bahmani-Oskooee, Goswamil and Talukdar (2005) employ the ARDL framework but retain the error correction term (including the lagged level variables) regardless of the F-statistics, so that not all of the coefficients they report are statistically significant.

\section{VII}

\section{Past and future: a comparison of South-South and South-North trade}

The previous section presented the results of an econometric analysis of income elasticities in South-South trade and in South-North trade. They provide mixed evidence for the hypothesis that South-South trade is typically characterized by higher income elasticities of import demand than South-North trade. On the one hand, economic activity in the United States, which is one of the key Northern markets, is characterized by comparatively high income elasticities for imports from the global South and thus represents an attractive export destination. Indeed, income elasticities of demand for imports from South America (as represented by Argentina, Brazil, Chile and Peru) are highest in the United States, i.e., higher than in intraregional South-South trade (within South America), in interregional South-South trade (from South America to Asia) and in South-North trade from South America to the eurozone (see table 2). When it comes to imports from Asia (as represented by China, India, Indonesia and 
the Republic of Korea), United States income elasticities are topped only by those found in intraregional SouthSouth trade within Asia. On the other hand, certain segments of South-South trade are characterized by relatively high income elasticities. This is particularly true for trade flows to Asia. In fact, Asian importers have higher income elasticities for imports from fellow Asian countries than have importers in the global North (the eurozone and the United States) and extraregional trading partners in the global South (South America). Also, the (unweighted) average income elasticity of demand for imports from South America is higher for Asian importers than for the eurozone (while it is lower for the United States, the other key Northern importer). In other words, Asia is quite an attractive destination (in terms of import elasticities) in both intraregional and interregional South-South trade. This does not apply to the same extent to South America, where income elasticities for intraregional trade are higher than those for eurozone imports from South America, but lower than those for Asian and particularly United States imports of South American products. Also, for trading partners in Asia, South America is a less attractive destination (in terms of income elasticities of import demand) than Northern markets.

These findings carry some important implications. For one thing, they indicate that strengthening trade ties with other countries of the global South might indeed be a promising path for developing countries to achieve diversification in growth sources and export markets as well as more stable and sustainable development. This notion is strongly reinforced by the recent export performance of developing countries (see figures 1 and 2), as well as forecasts for their future growth performance and import demand (see figure 3 and table 3 ). Figure 3 shows economic growth projections, the consensus among economists being that emerging and developing economies will grow considerably faster in the near future than advanced economies. Table 3 fleshes out this prediction by specifying the real GDP growth forecasts made by the IMF for a number of countries in the global North and the global South. Both the chart and the table indicate that in the years to come, developing countries, and particularly those of Asia, will outpace industrial countries in terms of economic growth, in some cases by a large margin. According to the IMF forecasts, economic growth rates will be about twice as high on average in emerging and developing economies as in the advanced economies from 2015 to 2019. While real GDP is predicted to grow at annual rates of between just $1.46 \%$ and $1.54 \%$ in the eurozone and between $2.22 \%$ and $3.03 \%$ in the United States, forecasts for major Southern powers such as China and India put growth there as high as $7.28 \%$ and $6.77 \%$, respectively. Table 3 reveals that growth forecasts for the industrial countries fall short of those for almost all the developing

FIGURE 3

Selected country groupings: growth forecasts for real GDP and imports, 2016-2020 (Percentages)

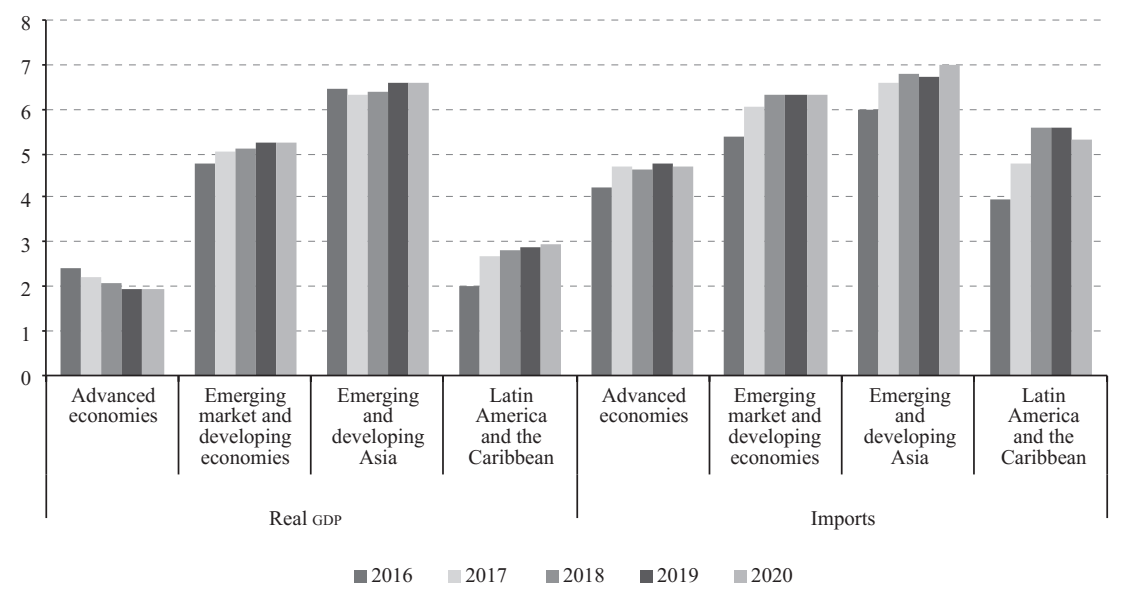

Source: Prepared by the author, on the basis of data from the International Monetary Fund (IMF), World Economic Outlook (WEO) database, April 2015.

Note: GDP: Gross domestic product. 
TABLE 3

Selected countries: real GDP growth forecasts, 2015-2019

(Percentages)

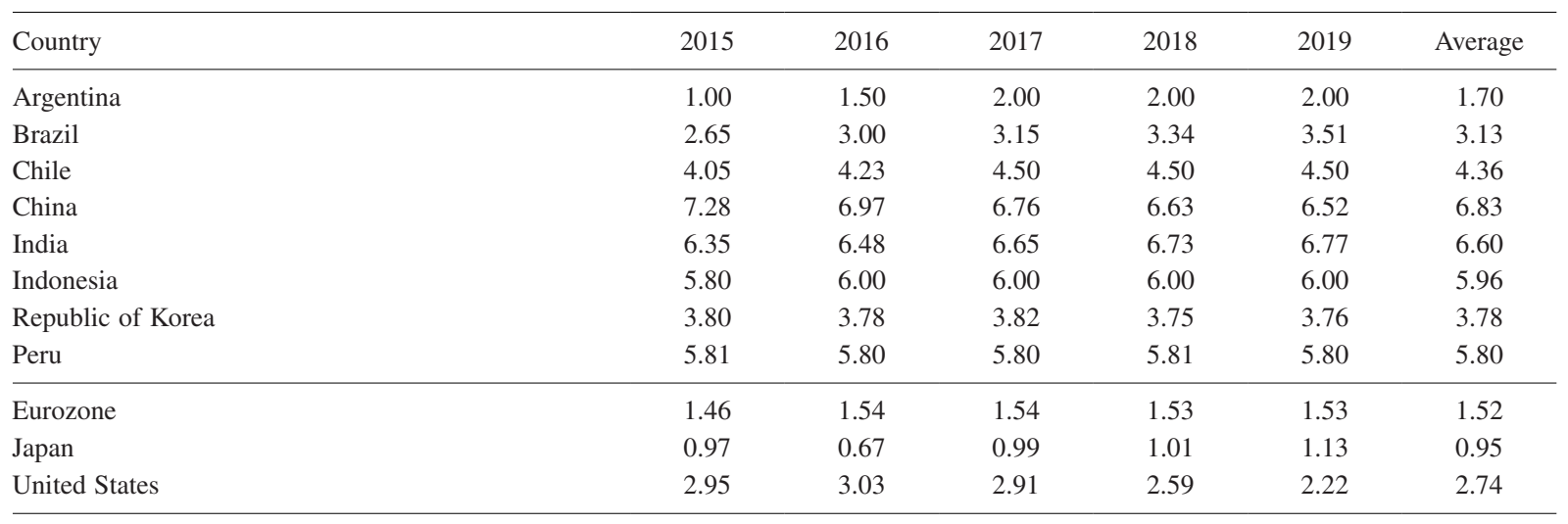

Source: Prepared by the author, on the basis of data from the International Monetary Fund (IMF), World Economic Outlook (WEO) database, April 2015.

countries considered here (the exception is Argentina, whose growth outlook has been significantly revised downward recently) for every single year for which forecasts are available. This has important implications for import demand: higher growth countries or regions are expected to exhibit a faster-growing appetite for imports as well. Indeed, as shown in figure 3, import growth is projected to be consistently between 1.0 and 1.6 percentage points higher in developing countries than in advanced economies over most of the coming years. Wherever they coincide with higher income elasticities, these higher import growth rates indicate that the potential spillover effects from economic activity in one Southern country to another are larger than those for SouthNorth relationships.

However, while the above figures strongly suggest that South-North growth differentials (in terms of both economic activity and imports) will persist, two important caveats have to be borne in mind. First, these are just forecasts, and growth figures may turn out worse than estimated. Some observers, such as ECLAC (2014), are in fact less optimistic, suggesting the world has entered a new period of slow growth that may continue for some time. Ongoing changes in the world economy, most notably the shift in China's growth model from exports to domestic demand (which has dampened its import demand and its role as an engine of growth for other countries), may well affect import demand elasticities. Second, it is important to keep in mind the difference between levels and rates of change. That is, even if both income elasticities and import growth rates for a given South-South trade relationship are higher than for a South-North relationship involving the same Southern exporting country, the increase in imports triggered by an increase in income in the Northern importing country may exceed the increase in imports triggered by a rise in income in the Southern importing country in absolute terms if the difference in the base levels (of income and imports) between the two importing countries is sufficiently large. While this applies to several of the bilateral trade relationships analysed above, the reasoning set out in the concluding section emphasizes the South-North differential in dynamics when assessing, from a policy perspective, the promise that expanding South-South trade holds for the economic development of the countries involved. 


\section{VIII}

\section{Policy implications and concluding remarks}

This paper has put forward some theoretical arguments for strengthening South-South trade links, not least in the context of widespread economic stagnation in the global North and the lessons provided by the recent global economic crisis. It has also documented the dynamic evolution of South-South trade in past decades and presented some indications that this dynamism is likely to continue in the future, further outpacing trade flows involving advanced economies. Meanwhile, the econometric analysis contained in this document, which focused on trade flows concerning a sample of Asian and South American countries and two key Northern markets (the eurozone and the United States), yielded mixed results with regard to the question of whether South-South trade is generally characterized by higher income elasticities of import demand than South-North trade. While relatively high income elasticities of import demand make developing Asia an attractive destination for both intraregional and interregional South-South trade, this is not the case with South America. Moreover, economic activity in the United States, one of the key Northern markets, is characterized by comparatively high income elasticities for imports from the global South, especially from South America, exceeding in many cases the income elasticity estimates for South-South trade relationships. However, the same is not true of the eurozone, where growth in real income triggers only relatively modest increases in imports from the Asian and South American countries studied here.

In terms of policy, the above findings suggest that developing countries should seek to strengthen and expand trade relations with other developing countries and to remove barriers to South-South trade. Accordingly, Fugazza and Vanzetti (2008) find that the emphasis on gaining access to Northern markets represents a missed opportunity for developing countries, as the potential gains from a removal of barriers to South-South trade are much higher (see also Anderson and Strutt, 2011). The main reason for these potential gains resides in the similarity of their stages of development and competitiveness levels, meaning that the countries involved do not have to fear being swamped by imports after trade liberalization. $\operatorname{UNCTAD}(2008$, p. xviii) echoes that argument, stressing that "South-South RTAS [regional trade agreements] can form part of a strategic scenario for enhancing (...) economic gains for developing countries.” Moreover, tariffs, other trade barriers and infrastructure obstacles are often higher for South-South than for South-North trade flows, so there is still quite some scope to facilitate trade flows between developing countries. Liberalization and facilitation of South-South trade can thus further strengthen economic ties between Southern countries, and indeed the number of free trade agreements between developing countries has grown considerably in recent years (see Wignaraja, Ramizo and Burmeister, 2012). Moreover, Athukorala (2011, p. 44) finds that "SouthSouth trade is largely complementary to, rather than competing with, South-North trade", which further reinforces the argument that seeking to expand SouthSouth trade is a sensible strategy for policymakers in developing countries. At the same time, they should strive to diversify and increase the technological content of South-South trade in order to maximize development dividends. This is particularly important in South American countries, as their exports to Asia are often largely confined to a few commodities, which creates vulnerability and limits the contribution of exporting to industrial upgrading, employment creation and broader economic development.

The evidence and arguments presented above provide some theoretical and empirical foundations for such policy recommendations. As has been observed, both economic growth and international trade promise to be more dynamic in the developing hemisphere than in the industrial world. Moreover, to repeat the central finding of the econometric analysis undertaken herein, for certain segments and certain bilateral trade relationships - particularly those involving Asian countries-, SouthSouth trade is characterized by higher income elasticities than import demand from the North. In these cases, further increases in the importing Southern countries' incomes will also benefit their Southern trading partners, which will see demand for their exports grow (with this growth being faster than if incomes in their Northern export markets expanded at the same rate as in the Southern importing countries). This relationship is likely to strengthen further as South-South trade barriers are gradually dismantled.

Taken together, these results suggest that the payoffs from fostering South-South integration might often be 
higher than those to be reaped from a further deepening of South-North trade relationships. The findings of this study thus indicate that promoting South-South trade can be a sensible and viable way for developing countries to make foreign trade a more promising and sustainable source of their economic growth. However, further research is needed to substantiate and refine these results, for example across countries and regions. In particular, similar analyses should be carried out for a larger sample of countries, covering South-South

ANNEX 1

\section{Data sources}

Import data were sourced from the Bureau of Economic Analysis (BEA) for the United States and from the IMF Direction of Trade Statistics (DOTS) for the eurozone and the eight developing countries in our sample. Data on exchange rates and GDP deflators or, alternatively, consumer price indices (CPIS) were drawn from the IMF

ANNEX 2

The estimation process

The first step in the estimation of the coefficients for each individual bilateral trade relationship was to run a regression on the full-fledged equation, i.e.:

$$
\begin{gathered}
\Delta M_{t}^{j}=\alpha+\sum_{i=1}^{n} \beta_{i} \Delta \ln Y_{t-i}+\sum_{i=1}^{n} \gamma_{i} \Delta \ln E_{t-i}^{j} \\
+\sum_{i=1}^{n} \delta_{i} \Delta \ln E_{t-i}^{j}+v_{1} \ln Y_{t-1}+v_{2} \ln E_{t-1}^{j} \\
+v_{3} \ln M_{t-1}^{j}+\epsilon_{t}
\end{gathered}
$$

where $\ln$ is the natural logarithmic form, $M$ is demand for imports from country $j, Y$ is real domestic income, $E$ is the real bilateral exchange rate between the home country and country $j$ at time $t$ (defined as the number of units of domestic currency per unit of foreign currency adjusted for domestic and foreign price levels) and $\varepsilon_{t}$ is the random error term. The second step consisted of a reiterative process of eliminating statistically insignificant differenced variables while retaining the lagged level variables. In a third step, an F-test was performed for linear restrictions on the final model, checking whether the coefficients for the lagged level variables for $Y$, trade flows that involve African economies especially. Moreover, the robustness of the empirical findings needs to be further tested through the application of different estimation methods. South-South trade and cooperation have received renewed attention in the past few years and can be expected to remain high on the agenda of policymakers in developing countries, so any additional empirical analysis will be welcome in their struggle for evidence-based decision-making.

International Financial Statistics (IFS) database, while GDP data were sourced from the IMF World Economic Outlook (WEO) and IFS databases and from the OECD Statistical Database (oECDStat). All data are quarterly. The number of observations varies for the different bilateral trade estimations, ranging from 43 to 206 (see also annex C). The typical time period covered is from the mid-1990s to 2011 or 2012, but in some cases data reach back to the 1940 s.

$E$ and $M$, which constitute the so-called lagged error correction, were equal to zero, i.e., whether the term $v_{1}=v_{2}=v_{3}=0$. The results of these F-tests, as reported in the tables in annex $\mathrm{C}$, informed the decision on whether to retain the lagged error correction term or exclude it from the equation. Pesaran, Shin and Smith (2001, p. 300) provide critical value bounds for the F-statistic. If the F-statistic is greater than the critical value bound, the null hypothesis of $v_{1}=v_{2}=v_{3}=0$ is rejected (the lagged level variables are cointegrated). In table CI(iii), they specify that the critical value bounds for the case with three variables in the lagged error correction term are 3.77 at the $10 \%$ level, 4.35 at the $5 \%$ level, 4.89 at the $2.5 \%$ level and 5.61 at the $1 \%$ level, respectively (Pesaran, Shin and Smith, 2001, p. 300). Comparing the results of our F-tests with these critical values, it was decided on a case-by-case basis whether to retain or exclude lagged error correction terms from the equation. In the event that the lagged error correction term is retained, the coefficient for the lagged level variable for $Y$, i.e., $v_{1}$, gives the long-run "equilibrium" income elasticity of import demand for the bilateral trade relationship under consideration. If, however, the lagged error correction term has to be excluded (going by the F-statistic), then only the short-run effect of a change in income on import demand is obtained. 


\section{Bibliography}

ADB (Asian Development Bank) (2011), Asian Development Outlook 2011. South-South Economic Links, Manila.

Amsden, A. (1987), "The directionality of trade: historical perspective and overview", Exports of Developing Countries: How Direction Affects Performance, O. Havrylyshyn, Washington, D.C., World Bank.

Anderson, K. and A. Strutt (2011), "Asia's changing role in world trade: prospects for South-South trade growth to 2030", $A D B$ Economics Working Paper Series, No. 264, Manila, Asian Development Bank.

Athukorala, P. (2011), "South-South trade: an Asian perspective", ADB Economics Working Paper Series, No. 265, Manila, Asian Development Bank.

Bahmani-Oskooee, M. and O. Kara (2005), "Income and price elasticities of trade: some new estimates", The International Trade Journal, vol. 19, No. 2, Taylor \& Francis.

Bahmani-Oskooee, M., G.G. Goswamil and B.K. Talukdar (2005), "Exchange rate sensitivity of the Canadian bilateral inpayments and outpayments", Economic Modelling, vol. 22, No. 4, Amsterdam, Elsevier.

Chang, T., Y. Ho and Ch. Huang (2005), "A reexamination of South Korea's aggregate import demand function: the bounds test analysis", Journal of Economic Development, vol. 30, No. 1.

Chatelain, J.-B. and A. Tiomo (2001), "Investment, the cost of capital and monetary policy in the nineties in France: a panel data investigation", Working Paper Series, No. 106, European Central Bank.

Dahi, O. and F. Demir (2008), "South-South trade in manufactures: current performance and obstacles for growth", Review of Radical Political Economics, vol. 40, No. 3, SAGE.

Debelle, G. and J. Vickery (1998), "The macroeconomics of Australian unemployment", Unemployment and the Australian Labour Market, G. Debelle and J. Borland (eds.), Keswick, Alken Press.

ECLAC (Economic Commission for Latin America and the Caribbean) (2014), Preliminary Overview of the Economies of Latin America and the Caribbean (LC/G.2632-P), Santiago.

Fugazza, M. and D. Vanzetti (2008), "A South-South survival strategy: the potential for trade among developing countries", The World Economy, vol. 31, No. 5, Wiley.

Goldstein, M. and M. Khan (1985), "Income and price effects in foreign trade", Handbook of International Economics, R. Jones and P. Kenen (eds.), vol. 2, Amsterdam, North-Holland.

Griffith-Jones, S. and J.A. Ocampo (2009), "The financial crisis and its impact on developing countries", Working Paper, No. 53, Brasilia, International Policy Centre for Inclusive Growth.

Grullón, S. (2012), "Price and income elasticities of disaggregated import demand: bounds test results for the Dominican Republic", Journal of Economics and Sustainable Development, vol. 3, No. 4.

Hanson, G. (2012), "The rise of middle kingdoms: emerging economies in global trade", Journal of Economic Perspectives, vol. 26, No. 2, Nashville, Tennessee, American Economic Association.

IMF (International Monetary Fund) (2011), "New Growth Drivers for Low-Income Countries: The Role of brics" [online] https://www. imf.org/external/np/pp/eng/2011/011211.pdf.

Kaplinsky, R. and M. Farooki (2010), "Global value chains, the crisis, and the shift of markets from North to South", Global Value Chains in a Postcrisis World: A Development Perspective, O. Cattaneo and others (eds.), Washington, D.C., World Bank.

Kaplinsky, R., A. Terheggen and J. Tijaja (2010), "What happens when the market shifts to China? The Gabon timber and Thai Cassava value chains", Global Value Chains in a Postcrisis World: A Development Perspective, O. Cattaneo and others (eds.), Washington, D.C., World Bank.

Klinger, B. (2009), "Is South-South trade a testing ground for structural transformation?", Policy Issues in International Trade and Commodities Study Series, No. 40, New York, United Nations Conference on Trade and Development (UNCTAD).
Kwack, S.Y. and others (2005), "Consistent estimates of world trade elasticities and an application to the effects of Chinese Yuan (RMB) appreciation", Journal of Asian Economics, vol. 18, No. 2, Amsterdam, Elsevier.

Lall, S. (1987), "India's economic relations with the South", Exports of Developing Countries: How Direction Affects Performance, O. Havrylyshyn (ed.), Washington, D.C., World Bank.

Lewis, W.A. (1980), "The slowing down of the engine of growth", American Economic Review, vol. 70, No. 4, Nashville, Tennessee, American Economic Association.

Milberg, W. and D. Winkler (2010), "Trade, crisis, and recovery: restructuring global value chains", Global Value Chains in a Postcrisis World: A Development Perspective, O. Cattaneo and others (eds.), Washington, D.C., World Bank.

Myrdal, G. (1956), An International Economy. Problems and Prospects, London, Routledge.

Ocampo, J.A. (2009), "Latin America and the global financial crisis", Cambridge Journal of Economics, vol. 33, No. 4, Oxford University Press.

Panopoulou, E. and N. Pittis (2004), "A comparison of autoregressive distributed lag and dynamic oLs cointegration estimators in the case of a serially correlated cointegration error", The Econometrics Journal, vol. 7, No. 2, Wiley.

Pesaran, M.H. and Y. Shin (1999), "An autoregressive distributed lag modelling approach to cointegration analysis", Econometrics and Economic Theory in 20th Century: The Ragnar Frisch Centennial Symposium, S. Strom (ed.), Cambridge, Cambridge University Press.

Pesaran, M.H., Y. Shin and R. Smith (2001), "Bounds testing approaches to the analysis of level relationships", Journal of Applied Econometrics, vol. 16, No. 3, Wiley.

Shaffaeddin, M. (2008), "South-South regionalism and trade cooperation in the Asia-Pacific region", RCC Policy Paper Series, Colombo, UNDP Regional Centre in Colombo.

Shirotori, M. and A.C. Molina (2009), South-South Trade: The Reality Check, Geneva, United Nations Conference on Trade and Development (UNCTAD).

Stock, J.H. and M.W. Watson (1993), "A simple estimator of cointegrating vectors in higher order integrated systems", Econometrica, vol. 61, No. 4, New York, The Econometric Society.

Thorbecke, W. and G. Komoto (2010), "Investigating the effect of exchange rate changes on transpacific rebalancing", $A D B I$ Working Paper, No. 247, Tokyo, Asian Development Bank Institute.

UnCTAD (United Nations Conference on Trade and Development) (2011), The Least Developed Countries Report 2011 (UNCTAD/ LDC/2011), New York.

(2010), Economic Development in Africa Report 2010. SouthSouth Cooperation: Africa and the New Forms of Development Partnership (UNCTADC/ALDC/AFRICA/2010), New York.

(2008), South-South Trade in Asia: The Role of Regional Trade Agreements (UNCTAD/DITC/TAB/MISC/2008/2), Geneva. (2005), Trade and Development Report 2005, New York.

UNDP (United Nations Development Programme) (2013), Human Development Report 2013. The Rise of the South: Human Progress in a Diverse World, New York.

UNIDO (United Nations Industrial Development Organization) (2006), Industrial Development, Trade and Poverty Reduction through South-South Cooperation, Vienna.

Uz, I. (2010), "Bilateral trade elasticities of Turkey", International Journal of Applied Economics, vol. 7, No. 1.

Wignaraja, G., D. Ramizo and L. Burmeister (2012), "Asia-Latin America Free Trade Agreements: an instrument for inter-regional liberalization and integration?", ADBI Working Paper, No. 382, Tokyo, Asian Development Bank Institute.

World Bank (2011), Global Development Horizons 2011. Multipolarity: The New Global Economy, Washington, D.C.

Yin, F. and S. Hamori (2011), "Estimating the import demand function in the autoregressive distributed lag framework: the case of China", Economics Bulletin, vol. 31, No. 2. 